\title{
Oñati's youth facing the armed conflict: Analysing the discourses of the first post-conflict generation
}

OÑATI SOCIO-LEGAL SERIES VOLUME 10, ISSUE 3 (2020), 616-641: PRACTICES OF MEMORIALIZATION AND THE PROCESS OF SOCIAL RECONSTRUCTION

DOI LINK: HTTPS://DOI.ORG/10.35295/OSLS.IISL/0000-0000-0000-1043

RECEIVED 28 SEPTEMBER 2018, ACCEPTED 17 OCTOBER 2018

\section{SAMARA VELTE* (D)}

\section{Abstract}

This paper analyses the discursive reconstruction of the Basque armed conflict in the oral narratives of the first post-conflict generation among Oñati's inhabitants, in order to observe how collective memory is being built and transmitted to the younger generations after the end of ETA's attacks. Using a discursive-historical approach and based on both in-depth and collective interviews, it focuses on three main aspects: how these adolescents categorise and evaluate events and actors of the violent past, the level of identification towards the events narrated, and the main canals through which both knowledge and attitudes are being transmitted. It concludes that adolescents perceive the conflict rather in its immaterial forms such as feelings and prejudices, and that they rely mostly on educational and familiar discourses when rebuilding the past. Some of the main voids identified are also signalised in this paper.

\section{Key words}

Armed conflict; youth; discourse analysis; memory; Basque Country

\section{Resumen}

Este artículo estudia la reconstrucción discursiva del conflicto armado vasco en la narrativa oral de la primera generación posconflicto de Oñati, con el objeto de observar cómo se está construyendo y transmitiendo a las generaciones jóvenes la memoria colectiva después del fin de los ataques de ETA. Utilizando un enfoque discursivohistórico y con base en entrevistas en profundidad y colectivas, el artículo se centra en tres aspectos principales: cómo los adolescentes categorizan y evalúan hechos y actores del pasado violento, el nivel de identificación con los hechos narrados y los canales

This research has been funded by the Institute for the Sociology of Law and the City of Oñati, through the Oñatiko Udala Grant 2018.

* Samara Velte (born 1991) is a PhD student at the University of the Basque Country (Barrio Sarriena, s/n. 48940 Leioa, Bizkaia, ES). Her research focuses on discourse analysis and memory processes. Email address: smvelte001@ikasle.ehu.eus 
principales a través de los cuales se transmiten el conocimiento y las actitudes. La conclusión es que los adolescentes perciben el conflicto más en sus formas inmateriales, como sentimientos y prejuicios, y que se apoyan sobre todo en discursos educativos y familiares a la hora de reconstruir el pasado. También se señalan algunos de los huecos principales que se han identificado.

Palabras clave

Conflicto armado; juventud; análisis del discurso; memoria; País Vasco 


\section{Table of contents}

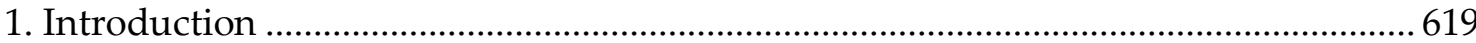

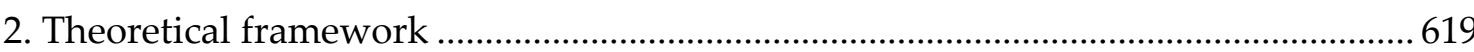

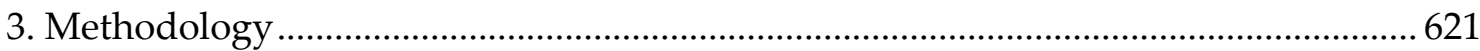

4. The Basque conflict in Oñati: the socio-political context of this research ..................623

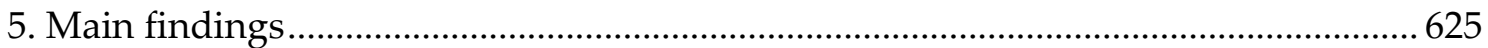

5.1. Categorisation and evaluation of the main actors involved .................................625

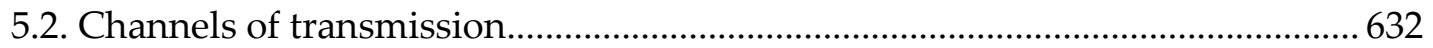

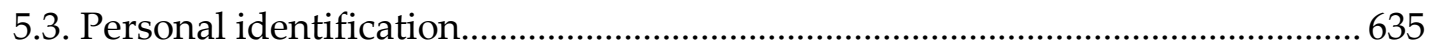

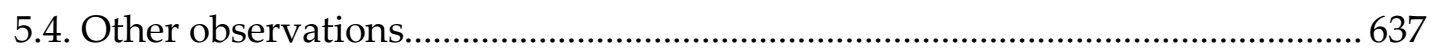

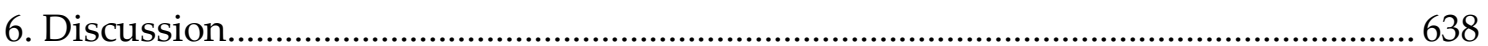

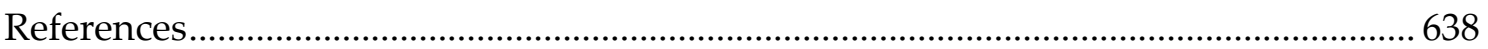




\section{Introduction}

As of 2018, the political situation in the Basque Country is evolving to a post-conflict era, marked by the end, almost a decade earlier, of ETA's attacks on Spanish and Basque politicians, military police and civilians, followed by its October 2011 statement announcing the end of its "armed activity" (Euskadi Ta Askatasuna 2011) and its complete breakup as an armed organization in May 2018, exactly 60 years after its creation and half a century after the beginning of its armed operations. We consider that these last ten years have been the beginning of a transition phase in the Basque Country, as there have been no material attacks at least from ETA's side. Nevertheless, there has been no formal peace process, nor are social debates being facilitated, which could help to de-escalate the conflict, bring the different sides closer and acknowledge the damage done to all victims. The very end of the conflict itself is still being disputed, as some of the main Spanish political parties, as well as some of the main platforms of ETA's victims - which in turn do not necessarily comprise most of the victims themselves - are claiming further steps.

In this context of disputed narrative-building - about whether the conflict has ended, and if so, who has brought it to an end, and whether it has been a defeat or a victory by any of the sides -, a new generation is entering the scene. This is the first generation that does not have direct memories about the most violent phase of the conflict (between 1968 and 2006); those who were born in 2000 - the so-called "millennials", who are reaching adulthood the year this essay is being written - will hardly remember the most important attacks and police operations that have marked the history of the Basque conflict. Therefore, the mental models these young people create about the violent past are necessarily based on external discourses, and the narratives they build are, at the same time, newly contextualised and re-significated discourses.

This article aims to identify some of these narratives and mental models, as well as the main channels through which knowledge and attitudes towards the violent past is being transmitted to the younger generations. As we will argue later, memory-building are strongly linked to discourse; therefore, we consider that Critical Discourse Analysis can be a useful tool to analyse the narratives about the past. Using a psycholinguistic and discursive-historical approach, the goal of this study is to identify the main linguistic strategies employed by the younger generations to re-build the memory of the violent past, as well as to position themselves in relation to the items narrated. Furthermore, this analysis can be helpful to identify some of the dominant discourses in the environment of these young adults, and this may prepare the ground for further research or for proposing interventions in the educational or institutional sphere that may favour attitudes and schemes of reconciliation among the younger generations.

\section{Theoretical framework}

This research is to be contextualised within the field of Memory Studies, and we propose Discourse Analysis as both a methodological and a theoretical tool to analyse the transmission of memory. Authors such as Maurice Halbwachs (2004) and Pierre Nora (2002) have demonstrated how the construction of collective memory implies a construction of collective identity, and Discourse Studies help us understand how these constructions materialize through language (Wodak and Fairclough 1997, Calsamiglia 
and Tusón 2012). This idea matches with Fivush's (2010) understanding of narratives, which he defines as following:

How and what is narrated about the past is pivotal for what is remembered. Narratives emerge in social interactions, in which certain events, and especially certain interpretations and evaluations of events, will be validated. Through multiple tellings, narratives become accepted (or contested [...]) evaluative versions of the past. (Fivush 2010, p. 90)

Therefore, every process of transmission of information and memory necessarily implies choosing among certain elements that are relevant for the social groups involved, in the exact situation in which this transmission is happening, while other elements remain forgotten. This process is strongly linked to the establishment of dominant discourses or narratives, which are, as Shahzad (2011) puts it, "technologies of memory", as they carry what will be remembered by a certain epistemic community, and, therefore, will constitute an element of their collective identity.

This idea can be linked to the principles of Critical Discourse Analysis (CDA), which understands language as a social practice, embedded within social relations, and, therefore, not unaware of the power relations that originate from and shape those social situations: those groups that hold power usually exercise this power also through language, in the form of linguistic capital (Bourdieu 2008). The discourses we create are, on one hand, characteristic of our position within the social situations, in which this discursive event is happening; on the other hand, they tend to reproduce and reinforce the existing status quo (Bakhtin 1979, Lemke 1995, Jäger 2004). This is why discourse has been interpreted by several authors (such as Foucault 1970) as a kind of violence which is exercised on those who lack the power to create dominant discourses. These are often unrecognised or minority groups who have no access to the official or main channels of transmission.

In order to understand how these dominant discourses influence the understanding of the social reality - and, therefore, also history itself -, we need to lean on van Dijk's sociocognitive theory (van Dijk 1987, 2003, 2005). This explains how external discourses influence the construction of mental models about concrete situations or historical events; it also presents the concepts of "ingroup" and "outgroup", through which speakers categorise the actors involved in a situation, and express identification with one or another, tending towards a positive presentation of the self and a negative representation of the other. These psycholinguistic mechanisms partly explain how the (re)construction of collective memory works. In this sense, we have an important reference: the discursive-historical approach developed by Wodak (De Cillia et al. 1999, van Leeuwen and Wodak 1999). This author, through a linguistic analysis of the oral discourses generated by the Austrian post-war generation, demonstrates how every narrative about the past is conditioned by the current situation of the speaker, and clarifies some of the psycholinguistic mechanisms through which the past is re-built when narrated, namely constructive strategies, justifying strategies, transformation strategies and destructive strategies.

In the context of post-conflict situations, silence is often more eloquent than the uttered discourse. It is exactly the case that we identify in the Basque Country, where, almost a decade after the end of ETA's attacks, there has been no peace process or reconciliation 
on a social level. The interest for this research arises from the concern about the lack of transmission in the Basque case, where the construction of collective memory is often being left to families and the private sphere, not without certain complexes and fears. As argued by Galtung (2013) and Lederach (1998), the construction of peace - the transformation of a conflict towards a non-violent expression - must include all levels, from the most visible to the underlying cultural violence, which is also composed by discourses and mental models that legitimize the former. In order for this to happen, it is essential to create spaces where the affected parties can meet and recognise each other (Reidy et al. 2015). It is also necessary to provide tools for the newer generations to reconstruct the past from a pacification approach. Only by doing that can we avoid the danger of exclusion in memory-building, i.e. the lack of self-recognition as a victim of the conflict, as well as of idealising the violence of the past or wanting to return to other scenarios, a phenomenon that has occurred in cases like Northern Ireland (Devine and Schubotz 2010) or Colombia (Wilches Tinjacá and Hernández Pérez 2016) and that can also be identified in a small part of the Basque youth.

This is perhaps the most special characteristic of the Basque case: unlike in Northern Ireland, where there was a peace process endorsed by the highest state and international institutions, or in Colombia, where citizens participated in a process of forums and endorsements on the agreements, in the Basque Country the peace process has not been recognised by the Government of Spain; for that reason, authors like Whitfield (2014) have baptized the Basque process as "virtual peacemaking". To date, there are still almost 300 people imprisoned related to terrorism and 220 unsolved attacks (Fonseca 2014). The history of the Basque conflict is hardly addressed in compulsory education, so that the knowledge and tools available to the new generations depend on the transmission within the families or by the media, most of which have proven to fail to overcome the mental patterns of confrontation, developing a so-called "mediatic antiterrorism discourse" and positioning themselves close to the Spanish Government (Idoiaga and Ramírez de la Piscina 2002, Murua Uria 2015). Some of the few studies done on this topic have shown that the Basque youth feels that there is a lack of information about the violent past, and that they perceive the topic to be a taboo issue (Usón González et al. 2017).

\section{Methodology}

For our study, six in-depth interviews and one focus group were carried out with six adolescents born between 2000 and 2002, all of them living in Oñati and attending two different schools in the city. 50 per cent of the participants were girls and 50 per cent were boys, and all of them took part voluntarily in the project. The interviews took place between May and June 2018 at the International Institute for the Sociology of Law, and each lasted between 30 minutes and one hour; the focus group lasted one and a half hours. In total, we gathered approximately six hours of oral data to be analysed. It is to be taken into account that the aim of this project is not to make a quantitative analysis of the opinions of Oñati's youth, but instead to identify some of the main narratives that evolve from their discourses, as well as the main linguistic strategies employed for their construction.

Therefore, the individual interviews consisted of two main parts. During the first, participants were asked broad questions, in order not to precondition the answers. This 
part involved questions such as: "Which is the first thing that comes to your mind when you hear the concept 'Basque conflict'?", "How would you explain the history of the conflict to a foreigner?" or "Which have been the main actors involved?". These questions, especially the second one, proved to be very fruitful, as they allowed the participants to rebuild their own version of the history of the conflict with the biggest possible freedom.

The second part of the interview involved more concrete questions that we considered relevant for the purpose of our study. These included questions about sources of information - such as "How has the issue been addressed in your family / at school?" -, their personal identification - "Do you feel that the conflict has had an influence on you? And if so, how?" -, and their moral evaluation - "Do you think justice has been done?". To end with, the participants answered a rather long questionnaire about certain actors or events that we considered to be important throughout the history of the conflict: among others, they were asked to describe the main armed parts involved - ETA, the Spanish Government and the military police -, as well as to list the main representatives of each group. In the last part of the interview, they were asked about different peace initiatives that have taken place throughout the history of the conflict.

The group interview involved exercises of a more practical nature: first, the participants were asked to complete a timeline of events, starting from 1958 and ending in 2018, positioning the historical moments and actors they considered important. The aim of this practice was not so much to identify how much they knew about the course of events, but to observe, on one hand, which were the actors and events they considered to be most important, and, on the other hand, how they argued about them among themselves. For the second exercise, participants were asked to mentally design and describe a hypothetical piece of art - a painting or a sculpture - that would represent the history of the conflict. This last practice proved to be fruitful, especially for the youngest participants, who had a harder time expressing certain ideas with words; furthermore, we consider that these kind of creative exercises allow participants to build narratives rationalising less than when they explain them orally - access to their mental models is therefore more direct.

As agreed beforehand with the participants and their legal tutors, audio of all interviews and collective exercises was recorded and afterwards transcribed. The interviews took place in the local dialect of Basque language, as this was the most natural format for the participants. This project is contextualised in a broader research work which involves adolescents from the entire Basque Country; therefore, the transcription was done in the normative register of Basque language. Relevant excerpts that are mentioned in this essay were then translated to English for this concrete purpose.

Once all interviews were transcribed, relevant excerpts were selected and tagged according to our analytic categories. These included four main categories, which we will discuss more thoroughly in section 5 of this article (Main Findings).

1. Categorisation of involved actors;

2. Sources of information;

3. Personal identification; and

4. Main narratives and discursive strategies employed to rebuild the past. 
As agreed with the participants, their name will remain anonymous in this paper. For information purposes, each excerpt is identified with the gender and age of the narrator (for example, using F-16 for a female, 16-year-old narrator).

\section{The Basque conflict in Oñati: the socio-political context of this research}

Although our research work covers the scope of the entire Basque Country, this article focuses especially on the reality of Oñati (11,348 inhabitants, as of 2016). This municipality, as will be discussed afterwards, is not very different from others with similar socio-political characteristics within the historical territory of the Basque province of Gipuzkoa, although it does have some peculiarities: the municipal plenary consist solely of abertzale parties, that is to say, the abertzale left - which holds 10 representatives out of 17 , and is therefore the ruling party - and the Christiandemocratic, economically liberal EAJ-PNV; both parties campaign for some level of selfrule, whereas the main political parties based in Madrid - such as PP and PSOE - do not have any political representation in the city council. ${ }^{1}$

It would seem logical that this socio-political context favours an atmosphere in which the Basque identity - both as a cultural and a political identity - is quite strong: this is easily transmitted to the younger generations, which would position themselves on the Basque side of the conflict; therefore, it is to be expected that tolerance towards acts and groups interpreted as resistance movements - such as ETA, in the past - is bigger than in other parts of the Basque Country. This is usually expressed in social events - such as festivities or demonstrations -, as well as through graffiti and other graphic expressions in the public space. Nevertheless, it is worth taking a look at the consequences that the conflict has had on the municipality itself in order to make hypotheses about the main narratives young people are confronted with.

According to official figures from the Basque Government (Fonseca 2014), 970 lethal attacks were perpetrated by several armed groups between 1960 and 2014. Most of them (849) are attributed to ETA and its subgroups; 27 to the paramilitary, state-supported GAL, and 42 to other Spanish "uncontrolled" armed groups such as BVE. At the same time, 4,113 cases of torture have been documented by the Basque regional government and the University of the Basque Country, of which $43.4 \%$ were inflicted by the Guardia Civil - Spanish military police,$- 43.3 \%$ by the Spanish National Police and $8.1 \%$ by the Basque regional police (Ertzaintza) [Etxeberria et al. 2017]. Nevertheless, grassroots groups working on historical memory claim that up to 10,000 people have been tortured since the end of the Spanish Civil War, during Francisco Franco's dictatorship and during the years of the conflict after the establishment of the parliamentary monarchy in Spain.

According to the Euskal Memoria Foundation (in Lizarralde 2017), 60 inhabitants of Onati were tortured in the past five decades. Most of the arrests in the municipality happened between 1971 and 1975, during the last years of the dictatorship (over 70, according to Lizarralde, 2017, p. 153). This is by far the quinquennium during which most people were arrested; it is followed by the years 1991-1995, when slightly more

\footnotetext{
1 Please note that we do not use the term "Basque nationalist" on purpose, as this could lead to misunderstandings: we consider this to be a pejorative term, and if used, it should be used in contraposition to "Spanish nationalist" parties.
} 
than 20 people were arrested. One of the main peculiarities of Oñati's political history is that there have been no major arrests since the end of the 1990s, which means that most of the inhabitants under 30 nowadays do not have any direct memories of their covillagers being detained. Unlike in other municipalities, arrests related to illegalised youth movements or the so-called kale borrok $a^{2}$ were either non-existent or have not been documented.

According to Lizarralde (2017, p. 153), 67 of Onati's inhabitants have been in prison because of reasons related to the armed and political conflict. As of 2018, three of them remain imprisoned; all of them are facing sentences of more than 20 years, which means that the participants of our research were born after these people were imprisoned; that is to say, they have never known them personally.

Oñati has also a history of political refugees which is worth mentioning. According to the Euskal Memoria Foundation, at least 36 inhabitants have fled for reasons related to the political and armed conflict at some point during the last five decades, mostly towards the French Basque Country, Venezuela, Belgium, Canada and Uruguay.

As for the deaths documented on both sides of the conflict, it is known that at least five inhabitants of Oñati were killed because of reasons related to the armed conflict. The most notorious of these were 26-year-old militant Angel Fernández in 1983, who was killed by the same bomb he was placing at a company site in Vitoria-Gasteiz; and Susana Arregi, the 25-year-old member of ETA who was killed in the 1990 events of Irunberri (Navarre). The official version about the latter stated that she committed suicide together with another ETA militant; acquaintances and political sympathizers claim that they were killed by the Guardia Civil. Besides of these two, at least three inhabitants of Oñati died during accidents while they were visiting relatives or friends in prison. These deaths are known as "victims of the dispersion policy", by which for years the Spanish government has held Basque prisoners in prisons outside - and often far away from the Basque Country, vulnerating the right of the prisoners to be close to their families.

On the other side of the conflict, it is quite clear that the main victims of ETA's activity have been the members of the Guardia Civil stationed in Oñati. Their presence and headquarters, close to the historical centre of the town, and physically as well as socially isolated from most of the local population, have been the cause for some of the main conflicts in the past decades, as they are often perceived as an intimidating presence. Most of ETA's violent activity was also aimed at them: between 1975 and 1987, at least eight members of the Spanish military police were killed either by bombs or in shootings. Furthermore, one of the main events that has endured in the collective memory of Oñati's citizens is the grenade attack on the Guardia Civil's headquarters in 1998; as Lizarralde recalls, "nobody was killed, but they managed to throw the grenades into the building" (Interview with Ander Lizarralde, conducted on 5 June 2018 in Oñati). In fact, Oñati is rather known as a provocative environment due to its annual Fan Hemendik Eguna, a popular festivity, which constitutes a protest against the presence of the military police and during which clashes have happened occasionally.

\footnotetext{
${ }^{2}$ Kale borroka literally translates as "street fight"; it involved mainly sabotage of infrastructure and disputes during rallies and protests.
} 
The most important question for us is: which of these events have lasted in the collective memory of Oñati's people, and how are they transmitted to the younger generations? Do they have enough vessels or technologies of memory from which they can re-construct their narratives about the conflict? Interestingly, we have learned that memory groups in Oñati have worked quite hard on this issue. Two squares in town have officially been named after the dead militants: the main square has a small graffiti which reads "Anjelen arkupea" - "Anjel's porch" -, and on the facade of the public secondary school, there is a plaque with the inscription "Irunberri plaza" on it, unofficially re-naming the square as "Irunberri Square", in reference to the 1990 events. In fact, several gatherings in the last years commemorating Susana Arregi's death have led to troubles with the police. According to Lizarralde, "the fear for that repression might be one of the main reasons as to why memory has not been transmitted" (Interview with Ander Lizarralde).

Some of our participants attend school in the same building at which the Irunberri Plaza plaque is placed. Logic would make us think that they do have the means to access this technology of memory, and that this should have an effect on their narratives about the conflict, accentuating the local events over others. However, this is not the case, as we will describe in the coming section.

\section{Main findings}

Our analysis focused on four main elements: how the youngsters categorised and evaluated the main actors involved in the conflict; which were the main sources by which the memory of the conflict was being transmitted; and how they felt personally about the consequences. Finally, we were able to identify some of the main narratives present in the adolescents' discourses.

\subsection{Categorisation and evaluation of the main actors involved}

As already mentioned, the first part of the interview involved open questions, one of the first was "Who has been involved in the Basque conflict?". The answers show two different "ideological squares" (a concept developed by Teun van Dijk; see van Dijk $2005,30)$, or, in other words, the participants build two different discursive schemata, polarizing two actors in each of them: on one hand, we identify clearly a macro-square opposing the category "the Basques" to the category "the Spanish". In fact, the pronoun "we" - one of the main identifiers of an ingroup - is mostly used as a synonym for the former. This can be observed in excerpts such as:

1) For example here, in a village like Oñati, if you don't feel Basque, then you are badly looked at because you are Spanish. And I am the first who feels Basque, but if someone doesn't have that feeling, why shouldn't we respect it? I don't know, there are some opinions, and in Spain it's the same: if you tell a Spaniard that you are Basque, it's the same, it's as if you were worse. (F-16)

2) Q: What does [the Guardia Civil] symbolize for you, what does it suggest?

A: It symbolizes that we should be in our country that it should be our country, and that for now it's not only ours, and that there are some foreigners here who additionally have come with a bad will and who will never be welcome. And that is demonstrated every year, every day. (M-16) 
The first excerpt shows a mental model which illustrates a situation - a mental model of confrontation between the categories "Basque" and "Spanish", representing two identities: the participant offers no description about the characteristics of each category - someone just is one thing or the other, but both identities are presented as mutually excluding -. The second excerpt relates the category "Spanish" - clearly presented as the other in this polarizing square - to one very concrete actor: the Guardia Civil police becomes the paradigm of the otherness - or, in this very context, of the Spanishness -, negatively characterised through the attributed "bad will". In this case, the ingroup is not made explicit, but just addressed using the first person - "we", "our country" ...-. The use of the noun "foreigners" - used to describe the outgroup - suggests that the ingroup refers to a local or Basque identity. Nevertheless, this we is stressed clearly in other excerpts:

3) For example, my granddad told me many times that for example they did... well, I don't know the names, but for example, the Francoists and so, they had a ring at school because they spoke in Basque, and when they heard someone during recess they gave it to him, and whoever had the ring at the end of the class was punished. And he told me that he was punished many times because he had a completely Basque family. And then also that they [the Francoists] shaved the hair off his cousin's head, and also that they gave her some strange oil that gave you diarrhoea, and then they took her onto the street to make fun of her, just because she was Basque. So, from that side, those who were Basque or who fought for the Basque language, I think they received what they shouldn't have. But also on the other side many dead people, although they were Spanish I think they received as well. I think it was both sides, but I can't tell exactly which group. (F-16)

This excerpt describes a situation evaluated as unjust: the category of the Other - "the Spanish", symbolized by the Francoists - is linked to the idea of repression, symbolized by the ring and the social mobbing: the description itself offers a negative presentation of the Other, and therefore does not favour identification, whereas the Ingroup is attached to characteristics that favour empathy towards the described social group: the category "Basque" is characterized as a victim identity - the expression "just because she was Basque" suggest that the woman didn't deserve the earlier mentioned oppression, because she didn't do anything else -. In this case, a collective identity is the reason for an unjust suffering. This is an idea which has a great power of identification, as national or cultural identities are understood as elements linked almost naturally and embedded very deeply into people's lives, unlike concrete behaviours or activities which can easily change. According to this mental model, Spaniards use repression against Basques because they are Basque, not because they have done something. Furthermore, this positive self-presentation is enhanced by the example used by the participant in her narrative: the character that gives voice to the ingroup is a child, a symbol of innocence.

As for the concrete context of the armed conflict between 1958 and 2011, we have observed that our participants included ETA in the "Basques" category, but, at the same time, differentiated strongly between the Basque society and the armed group. This led us to identify a second polarizing square, within the first one: when the outgroup "the Spanish" is taken out of the scheme, ETA itself becomes often the outgroup. This is suggested in the next excerpt: 
4) You can be Basque but feel embarrassed by many things that have been done on the side of the Basque Country, and that happens to me: $\underline{I}$ am very Basque, $\underline{\text { but }}$ often I feel embarrassment in front of some actions ETA has done. (F-16)

In this case, a clear separation is perceived within the category "Basques": it enhances a polarizing square that we could summarize as "ETA vs the Basque society". This contradiction is expressed through the connector "but": the last part of the sentence works as a disclaimer of the first.

As the definitions given by the participants were often very general and abstract, they were asked to define the main armed actors of the struggle: ETA and the Spanish Government. We have summarized the answers in a table, reproducing the expressions used by the narrators as precisely as possible: 
TABLE 1

\begin{tabular}{|c|c|c|}
\hline & ETA & The Spanish Government \\
\hline $\begin{array}{l}\text { (a) Definitions / } \\
\text { descriptions }\end{array}$ & $\begin{array}{l}\text { - “A terrorist group that acted in } \\
\text { favour of the Basque Country". } \\
\text { - "A terrorist group”. } \\
\text { "An armed group that acted in } \\
\text { favour of the Basques or the Basque } \\
\text { culture”. } \\
\text { - } \quad \text { The aim] "Autonomy". } \\
\text { - Divisions: ETA(m) and ETA(pm). } \\
\text { - "Cold, secret". }\end{array}$ & $\begin{array}{l}\text { - "Repressors". } \\
\text { - Two-faced: dictatorship and } \\
\text { democracy. } \\
\text { - } \text { [The aim] "One Spain, one and } \\
\text { united”. } \\
\text { - } \text { [The aim] "To eliminate [the } \\
\text { Basque] nationality”. }\end{array}$ \\
\hline $\begin{array}{l}\text { (b) Concrete } \\
\text { actions }\end{array}$ & 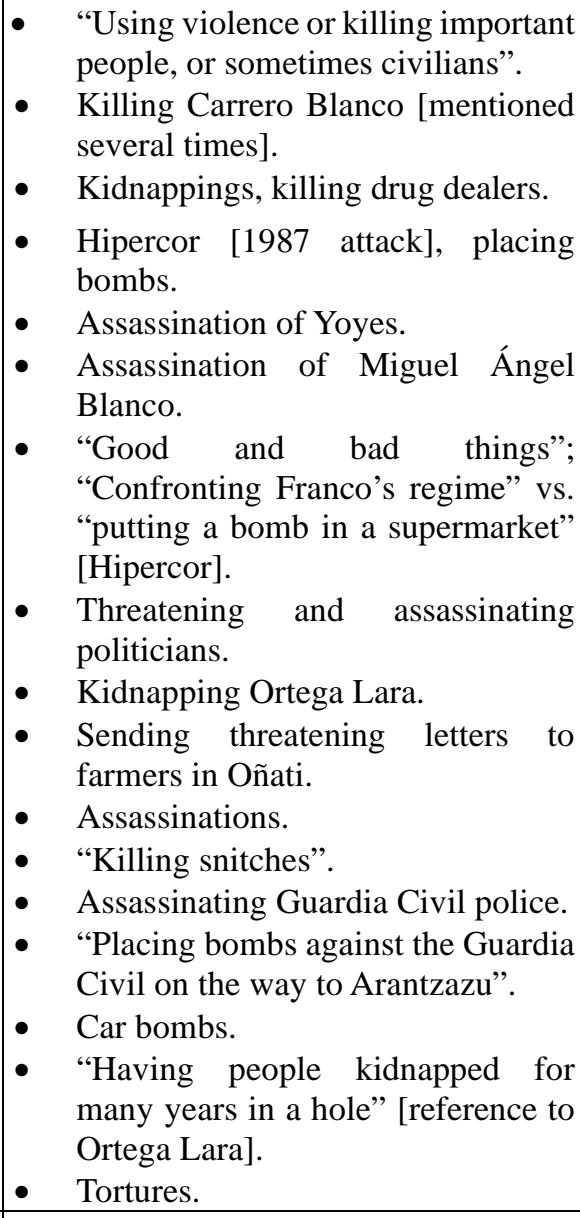 & 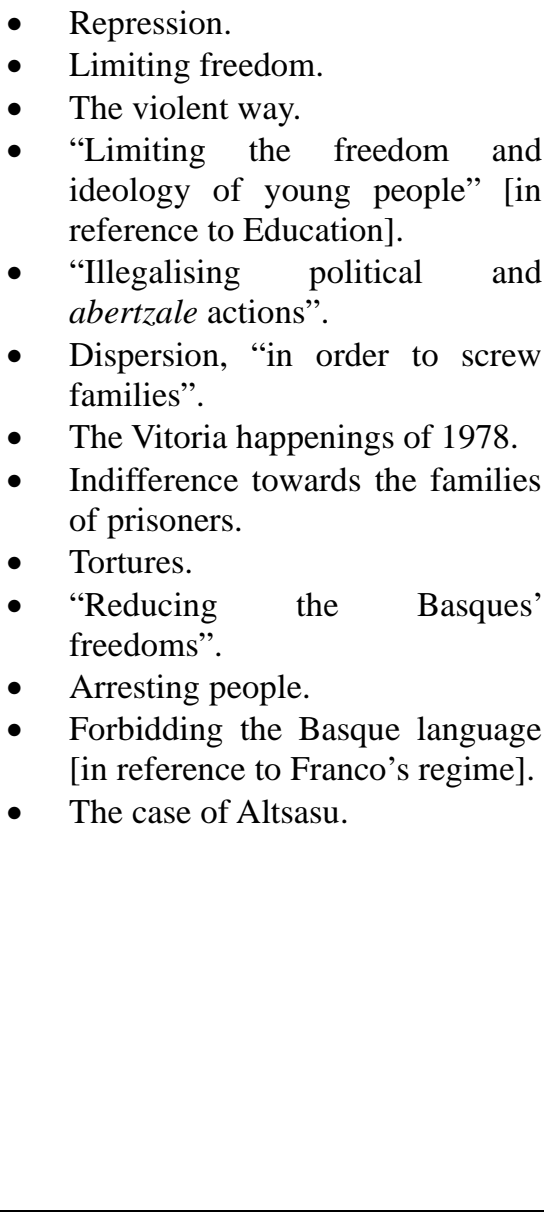 \\
\hline $\begin{array}{l}\text { (c) Main } \\
\text { representatives }\end{array}$ & $\begin{array}{l}\text { - Argala: "Within the violent } \\
\text { militants, an intellectual”. } \\
\text { - Joseba Sarrionandia. } \\
\text { - Txiki: "The last one they killed”. } \\
\text { "There was also Susana [Arregi], a } \\
\text { girl from ETA". } \\
\text { - Josu Uribetxeberria. } \\
\text { - The narrators friend's father: "He } \\
\text { tried to kill the King". } \\
\text { Arnaldo Otegi: "Directly an } \\
\text { intellectual”. }\end{array}$ & $\begin{array}{l}\text { - } \text { Francisco Franco. } \\
\text { - Juan Carlos I, former King of } \\
\text { - Cpain. } \\
\text { - Fénovas del Castillo. } \\
\text { the GAL movement from the top } \\
\text { to the bottom”. } \\
\text { - GAL. }\end{array}$ \\
\hline
\end{tabular}

Table 1. Categorisation of the main actors involved in the Basque armed conflict, as represented in the words of our participants.

Based on this categorisation, it is possible to observe several phenomena: 
a) Both actors are portrayed rather negatively. In ETA's case, two responses include a positive element: to act in favour of the Basques and the Basque culture. Nevertheless, demonizing descriptions predominate, such as the expression terrorist group. This leads us to the conclusion that ETA's intention - the aims - might be approved of, but not the way these were pursued - violence. In fact, we could identify this narrative in other discourses such as:

5) Well, no one likes to imagine his granddad tied to a tree, or whom would have been my great uncle... well, the one who was a truck driver, well, dead. So on that side, I do have this thing, I don't know, maybe a bit of a despise towards ETA's violence, $\underline{\text { but on }}$ the other side I do see, maybe it's a way, I mean, maybe a reason for me to say this is that they were my family, because if it were another family and if it were one - well, you know, he [the great uncle] was supposed to be a person linked to drugs - , maybe I wouldn't say the same. Therefore I can't... I mean, being objective, I might criticize that they killed a member of my family or someone else, but seeing how ETA's actions

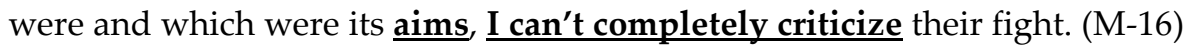

In this excerpt, the narrator makes use of a rationalisation strategy in order to reconstruct his narrative about the armed conflict: he searches for a reason to understand the feelings that ETA's attacks on his own family have created, rationalises the situation by introducing a hypothetical situation - through which he distances himself from the actual reality of facts -, and justifies it with the feelings produced by ETA's aims - with which he sympathizes. This contradiction is clearly expressed through the connector "but", which marks the contrast between ETA's ways - the violence, or the killings, in this case - and its intentions - the mentioned "aims". The last part of the excerpt works as a disclaimer for the former. Excerpt 5 is therefore a good example of what we call a "justification-through-aims-narrative": ETA's actions are understood and approved as far as they are guided by an interest that is shared by the ingroup; there is no demonisation of the armed group in these discourses, but a critical stance towards the use of violence.

b) It is also remarkable that most of the first thoughts that come to the participants' minds when asked about the conflict - especially about ETA - are the most violent and spectacular actions; either because they left a large number of victims or because some of these victims were well-known people. They are usually also events that have received great attention from the media, and they generally portray the most violent side of ETA's activity. Other concrete campaigns such as the one against nuclear energy or actions that have left no or fewer victims are generally absent in these discourses. There could be several reasons for this; among others, the approach of the question itself, as the participants were asked about the conflict, and they generally seem to relate this concept to a scenery of violent confrontation. Nevertheless, as we have noticed and confirmed during other parts of the interviews, the lack of knowledge about elements that go beyond armed activities is manifested in many answers.

For the adolescents who participated in this research, ETA is portrayed mainly by its attacks, rather than by its ideals, vindications or slogans; in other words, the armed side of the organization has endured in their imaginary, rather than the political side. This image matches with the main mediatic discourses about ETA (see "mediatic counterterrorism", in Idoiaga and Ramírez de la Piscina 2002, or Velte 2016), and it 
shows a process of distancing: even though most of the participants identify as abertzale, they do not consider ETA to be a political referent.

c) It is also meaningful that the interviewees remember in greater detail ETA's actions than those of the Spanish Government: names of places or people, as well as descriptions of actions, are more abundant in their narratives, whereas in the case of actions attributed to the Spanish Government, the categorisations are more abstract and generalistic ("tortures", "repression", "limiting freedoms"), and the narrators do not provide any concrete names, authors or time-space references for them; often, when asked to provide examples, they were unable to do so.

d) From a gender perspective, it is striking that the concrete actors the youngsters remember are all male: most of them are related to the military side of the conflict or represent political elites. After them, local references are mostly mentioned: cases transmitted by age cohorts, or events that happened in Oñati and its surroundings. During the first round of definitions, only two women were mentioned: one, as one of ETA's victims (Yoyes), and the other one as a militant (Arregi, a local reference).

e) Most of the references that have endured in the memory of the participants - or those which have arisen as first thoughts, and are therefore predominant mental models - are events or characters who have become very mediatic; many of them took place long before the narrators were born. A clear example of this is the assassination of Luis Carrero Blanco, which has appeared during almost every interview, and which is probably ETA's best-known attack. To a lesser extent, but still remarkable, is the presence of the Hipercor attack in 1987 and the assassination of Miguel Ángel Blanco in 1997 - both are considered to be turning points in the public opinion towards ETA, as the victims were civilians or very low-profile politicians - or the mention of Joseba Sarrionandia, who is actually better known as a writer than as an ex-militant. After those mediatic cases, local references are mentioned most frequently: the name of Susana Arregi appeared once during the interviews - although the narrator was not able to provide any more details about her -, as well as Josu Uribetxeberria's. The latter's case became well known during 2012, as he was suffering cancer in prison. The descriptions provided by our interviewees suggest that they know Uribetxeberria's case rather for being from the region and for the illness he was suffering during the last years than for the details of his imprisonment: very few mentioned him being involved in Ortega Lara's kidnapping. We consider this a natural consequence of the construction of memory: epistemic communities generally recall in greater detail local references and recent events.

f) As for the chronological narratives, we have observed two interesting phenomena. On one hand, the narrators clearly divide two phases: firstly, the period until the establishment of parliamentary monarchy during the end of the 1970's, and secondly, the period after 1978. ETA's actions are evaluated depending on the period:

6) So at the beginning what the fascist parties did was that, well, they imposed their own thing, in any case, and that was usually done with violence. With violence and terror. And what ETA did was, at the beginning, to confront that, but then a moment arrived when it was not known how to leave or how to end, and where it did things that weren't necessary just to continue being there, to have a presence.

Q: Which was that moment? 
A: Well, for example, when there was already a transition period, then a democracy was established, although now it is being questioned whether things have changed a lot, but from then on, from one moment on there was no need to continue with the armed struggle. It was a moment of peace. (M-16)

In this excerpt, it is quite clear that the narrator draws a limit during the 1978 Transition: actions before that are justified through the negative presentation of the Other "violence" and "terror" are attributed to the Spanish Government during Franco's era, portrayed as "the fascist parties" -, and actions that took place after that moment are evaluated as unnecessary - implying that the ones before were necessary -. This excerpt coincides with another narrative that we have identified quite often: the resistance narrative, or the justification-through-necessity-narrative. According to this mental model, ETA's armed attacks emerged as an unavoidable response to the armed and political oppression that the Spanish government was exercising in the Basque Country during the dictatorship. The armed conflict is therefore naturalized and justified by the political context, but this justification loses grip as the political context changes: it is no longer receiving the same support after the end of Franco's rule. This is made explicit through the connectors "at the beginning" and "but then". This is enhanced by the use of an impersonal verb: "It was now known". By eliminating the subject - ETA -, the speaker dissolves the authorship behind the action; that is to say, those actions become a naturalised, unavoidable happening in discourse, instead of a decision of a very concrete actor.

However, the interviewed participants seemed to have more difficulties to evaluate the actions of the Spanish Government. They often mixed up events and actors that emerged before 1978 and after it, relying strongly on events that happened very early during Franco's dictatorship. This can be observed not only by how often these events are mentioned, but also through the discourse markers that denote the speaker's stance towards the events that are narrated: the adolescents use remarkably fewer expressions of doubt when speaking about events that happened before 1978 than about more recent ones. The more recent events are described through expressions that often include pet phrases such as "I guess", "well", "not sure", "maybe", "I think" or "I believe". Explanations involving events before 1978 are generally more straightforward constructions, in a rather categorical tone. Expressions denoting doubt are a sign of distancing oneself from the narrated events. They create a space of negotiation in the discourse: the narrator distances himself from what he is asserting, and accepts some discursive room in order to negotiate whether what he or she is saying is true. These are mental models that are more open to change and can therefore be influenced more easily. An example of this is the prominence with which the paramilitary organization GAL has emerged in many interviews.

7) GAL is a paramilitary group that the police of the state, well, I have heard that it was created under PSOE's government; it was a terrorist group which, well, dedicated itself to hunting terrorists.

Q: Where was it active, which were its victims?

A: Well, for example, Kattu was the first victim in 84 . There have been some others, well, I'm not sure whether the massacre of Pasaia was done by members of GAL or the Guardia Civil. Then there were others who could be involved with GAL, as I said, with the GAL or the Guardia Civil: Lasa and Zabala, and cases like that. (M-16) 
8) Q: You mentioned GAL. What was it?

A: A group that the government created to confront ETA - another armed group.

Q: Where was it active, what did it do?

A: Well, against ETA, I don't know where or how. I mean, how, well, with weapons, doing attacks and such, I guess, but I don't know.

Q: Where have you learned about GAL?

A: Well, I've always heard 'GAL' - 'What's GAL, what's GAL?'. And it was another group that confronted ETA. (M-15)

Both excerpts are quite illustrative: on one hand, GAL becomes a predominant image in the mental models of these youngsters because it is an armed group, and therefore, part of the violent expression of the conflict. This is suggested by the metaphor "hunting terrorists", as well as the descriptions "paramilitary group" and "armed group". Furthermore, we can observe quite clearly the difference between expressions that show certainty - and therefore, a greater implication and less distancing from the narrated events - and expressions that show doubts. Utterances such as "Kattu was the first victim in 84" or "A group that the government created to confront ETA" show no sign of doubt and hence, the narrator shows a great commitment to the truth of the facts that he is describing: this mental model is therefore steadier than others. From a linguistic point of view, these are constructive strategies which aim to establish a contract of truth in the narrative: by using structures that offer no space for negotiation or nuances, the narrator positions himself very closely to what he is asserting. Distancing occurs when we get into details about the issue: narrators show a greater uncertainty when describing GAL's actions. Our hypothesis is that this is related to the fact that shortly before the interviews were carried out, the Basque public television had shown a documentary about GAL: it seems logical that those youngsters who saw the documentary spoke with greater certainty about the events shown in the film, as the latter created a sort of true version to rely on. We will further elaborate on this idea in the next section.

\subsection{Channels of transmission}

The second question we considered relevant for our analysis was: which sources of transmission are available to the younger generations to build on their historical memory, and which ones have the greatest influence on their mental models? The latter is rather difficult to establish, as it would need a cognitive investigation, further than analysing only discursive material. However, the oral data we have collected can be used as a trace to identify some of those influences, that is to say, which are the main truthestablishing sources for those youngsters.

a) Home

During our hypotheses, we had assumed, by logic, which the main channel through which recent history is being transmitted is the family. As we have observed, this is only partly true: ideas transmitted by older relatives do have a great effect on the topics that are considered important by the adolescents; they do not, however, receive the same level of legitimation as educational discourses do. Transmission within the family is often done in the form of story-telling: 
9) ETA killed an uncle of my dad, during that time when ETA killed drug dealers; he was supposedly a dealer or something, it has not been clear why it was. And then my grandpa was also for one day - he was a taxi driver, and it seems that ETA needed his car or something, and yes, he was kidnapped for a day, tied to a tree. That, on my dad's side. But I think that my dad's stance is more critical, not because of that, but because his Christian ideology and so, against violence and so. Mom is also a Christian, but she might see that when there is need, there is need, and that it is unavoidable, or that maybe it shouldn't be avoided.

(...).

Well, yes: he told me how everything happened that day, and it might be remarkable that ETA, even though no one would like to be tied to a tree while they take your car besides, that car was the only source of income in a household of four children... That might not be something you like, but as far as he said, the ETA people did not treat him badly. The car appeared undamaged and they didn't hurt him. (M-16)

These two excerpts, taken out of the same interview, contain several characteristics worth mentioning. On one hand, the channel of transmission is a story, a structured narrative: this is a very common resource when transmitting memory. The narrator uses a story as an example that illustrates the whole conflict, oversizing elements that are important to him - for example, ETA's campaign against drug dealers - because it affected his own family - it is not by chance that this interviewee was the only one which mentioned that campaign. There is also a tendency to present one's own family in a positive way - as a victim, for example -, although in this case that feeling collides with the idea that ETA's actions were morally acceptable. The speaker sorts that contradiction out by drawing on a rationalising strategy: he relativizes ETA's actions through an evaluation of their consequences - as far as his family is concerned, there was no physical harm.

However, many participants have expressed difficulties to speak about the topic within their families. This is often expressed through feelings of fear and embarrassment, as the participants themselves acknowledge that they do not feel comfortable when talking about the topic:

10) I know that he [a prisoner, an acquaintance of the speaker's parents] studies in prison, that he is like an educated person. I don't know. I feel awkward about asking my parents, so I don't know much about it. In the end it's like a harsh topic, so I searched for information about what he did, but I don't know much. (F-17)

11) Q: Do you know any prisoner?

A: A friend of my dad's. She used to be active in ETA, she got out of prison and she was - when she arrived in town, people gathered. I didn't go, but dad told me how he was there.

Q: What's her case like, what is she like?

A: Well, I know she was a girl. (M-15)

12) There are a lot of prisoners and knowing their story doesn't bring me anything, because it won't change. If you tell me that a prisoner has killed a person or has killed five, I won't tell you that I understand, I can't tell you whether I would be able right now to kill five people, but I won't condemn those assassinations either. (M-17) 
In the first two excerpts, the interviewees are talking about friends of their parents, who are or were involved in the armed side of the conflict. Both express some level of frustration because they feel that they don't know much about these people, and a feeling of anxiety towards the topic itself. This might be a sign that the young people still perceive the armed conflict to be a taboo in society, especially when it comes to concrete people categorised as part of the ingroup. This perception can lead to denial, as we can observe in excerpt 12, where the narrator affirms that he doesn't want to know more about the prisoners "because it won't change anything".

b) Education

One of the most remarkable phenomena this research has observed involves transmission at school. On one hand, the interviewed adolescents do not consider school as one of the main channels of transmission: most of them stated that what they learnt about the history of the conflict in formal education was too little. Nevertheless, their discourses show great certainty when they speak about elements learnt at school; that is to say, information received in the classroom is reproduced with fewer phrases that denote doubt or distancing. In other words, it seems easier for the adolescents to admit lessons from school as objective truths than to admit their parents' stories, which they would often justify. This highlights the importance of educational institutions during the process of memory transmission. As we have noticed and already mentioned before, there is a big difference on the level of certainty expressed by the youngsters between events that happened before 1978 and after that. This might have a very concrete reason: the topics in most history books cover the period up to the end of the Franco regime historical events after 1978 are treated rather as exceptions. This has a direct effect on the narratives of the younger generations: they relate with great certainty what happened until 1978, often oversizing anecdotes from the Spanish Civil War and the Franco regime. It would seem logical that they remembered recent events more accurately - among others, because it was the period their parents experienced -, but this is not the case. There might be two reasons for this: on one hand, it seems that the topics emphasized at school endure stronger in the memories of the adolescents; on the other, it might also be that they perceive it psychologically and socially safer to assimilate events that are further away in time than those which are closer, more controversial and not perceived as objective truths.

\section{c) Age cohorts and social atmosphere}

Most of the personal cases that have arisen during the interviews have been transmitted to the narrators by other adolescents. This shows us that close events have a greater chance of enduring in memory. These narratives are generally acknowledged as very credible - they are retransmitted with very few expressions signalising distancing -; therefore, we can argue that friends and acquaintances of the same age generally have a great influence on the political socialization of young people. So does presumably the social atmosphere, as the interviewees acknowledge that there exists a kind of general opinion about the issue. Nevertheless, none of them has mentioned any of the local memory technologies identified in section 4: either they don't know about those elements, or they do not consider them relevant. In addition, the participants have expressed that the history of the conflict has little if no space at all in most of their everyday conversations; the effect of age cohorts is therefore strong, but very seldom exercised. 
d) Media

Interestingly, none of the participants has explicitly mentioned media as a source of knowledge about the conflict - the interviewer has had to ask about the main newspapers, social networks and other media they consume. The only exception has been the mention of a television programme. Therefore, it is difficult - if not impossible - to state to which extent media influences the mental models of these adolescents, although it is clear that it does have an effect. This is expressed in language through language colonization, when participants use expressions and metaphors that are generalized in the press but do actually contradict the youth's narratives. This would be the case of the use "terrorist group" - when talking about ETA -, "executioner" or "ETA's puppies". Therefore, we can assume that the media do exercise some kind of gas influence that the receiver does not identify clearly but that influences his or her mental models. They are part of a social atmosphere that, in this case, often collides with the discourses these youngsters have in their close environment. This is proven by the fact that they only identify those mediatic discourses that challenge their pre-established mental models:

13) Q: Are you happy with the information you get from the media?

A: No. For example, now, they have given very little importance to the issue of Altsasu; there was more of it in social networks than in the media. Cuatro, for example, has given none to it. (F-17)

\subsection{Personal identification}

The third part of our analysis comprised the level of identification or commitment the adolescents show when speaking about events of the violent past, and whether they relate events or actors from the past to current problems. In order to create discourses about this issue, first we confronted them with an open question: "Do you feel that the Basque conflict has affected you?". The first - conscious - answer, in almost all cases, was "no", to a bigger or lesser extent of certainty. However, later, during other responses, the participants have suggested some ways in which they feel affected by the conflict. This impact is perceived mainly in the form of prejudices and stereotypes against them, and in a more abstract or cultural way. We will try to explain this in detail.

14) I think that often a Basque person is defined by ETA you know? It has happened to me many times, for example, when I went to the United States in summer and one from Madrid asked me once whether they taught $\underline{\text { us }}$ to make weapons at school. And I was like, 'What, sorry?'. Or using weapons, I don't know how the question was. So I've always said that I feel very Basque, but for example I have never been in favour of ETA. (F-16)

15) Q: Do you feel that the Basque conflict has affected you?

A: Yes - not me directly, but my parents and so. Because they go to the visits [visiting prisoners], and me, personally... as I said before, in the end, the prejudices people from outside have affect you, but apart of that, $\underline{\text { no. }}$ (F-17)

In both cases, the narrators make explicit that they feel victims of prejudices. These are understood to be preconceived ideas about the Basque people by people outside of the Basque Country: that is to say, the younger generation feels that it suffers some kind of criminalization because the categories "Basque" and "ETA" are often linked in the minds 
of the outgroup. Interestingly, the second narrator has indirectly experienced one of the most visible consequences of the conflict: a friend of her parents is in prison, and they visit that friend regularly. Nevertheless, she does not identify this as an effect the conflict has had on her.

Prisoners generally seem to remain as a second-level effect of the conflict in the participant's minds: they do not come up that often in their discourses, unless the interviewer has asked about them. Except for cases that they know about personally which, as we have already seen, face an extra difficulty because the youngsters don't feel comfortable when talking about them -, prisoners are portrayed as a uniformed collective. In some cases they are described as victims of the conflict. It is in those cases when the narrators feel most identified with them:

16) Well, maybe it was when I was little and I used to enter Arrano with my parents to have a drink, and on the bar I would see those pictures and next to them a silhouette of a prisoner painted in black, saying: 'You could be the next one and here are a lot whom we haven't mentioned'. That has diminished; in the end, now there are only three left, but it is something close, something that you have always experienced since you were little, maybe you don't experience it directly, but they have always been there and you have witnessed that, and although you might not have something with them in your personal relationships, it is something that makes you think that you could be the next one and that you could be the next one serving a 40 year long sentence. And the youth from Altsasu are an example of that. (M-16)

17) I think that also the families of the prisoners are victims. Because in the end we have dispersion now; many people have suffered the consequences of it without being guilty. For example, my friend, his dad is in Cordoba. There is that kind of victim, and there is the kind of victim created by itself, for example the one that was kidnapped or so, or another one is the family. A family that has had an attack or something. And then the terrorists themselves, having their families so far away, can be victims as well. In the end, we too suffer that, from those who are against us... well, in the end... I don't know how to explain. Now there is this something against the Basque Country: on one hand, we also suffer those consequences. (F-17)

These two excerpts are good examples of the level of identification our participants show towards certain expressions or effects of the conflict. Firstly, they feel that the problem of the prisoners is mainly one that affected the generation before them; nevertheless, rather than the person itself, they recognise the figure of the prisoner, which works as a normative mechanism, somewhat of a warning or a social norm. On the other hand, there are some issues of actual interest which they do relate with the conflict: these are, as for the year 2018, the events of Altsasu - where eight young people were imprisoned because of a bar fight involving two Guardia Civil policemen off duty - and the clashes during Oñati's annual Fan Hemendik Eguna. Finally, both excerpts show a great level of identification with the events narrated, as they either rely on personal experiences or use first person verbs.

Another relevant finding is that the interviewed adolescents seem to experience the conflict in immaterial forms, such as feelings and ideas, instead of in a material way which could be physical repression, the existence of prisoners, the presence of an exceptional military police, or the fear of actually suffering physical harm or some kind of physical deprivation of liberties, which are usually the topics that are mostly 
addressed in the political sphere. This has been expressed several times during our interviews, especially when asked whether they think the conflict has ended:

18) I think that a conflict does not end - even though now there's no armed struggle... well, yes, even though it is not present, I think that a conflict does not end until that hate disappears. And I think that that hate will never disappear. (F-16)

19) Q: Would you say that the conflict is over?

A: No. Because the conflict itself yes, but yet, as I said before, you can see it in the case of Altsasu: in the end, it still conditions us and there continues to be this feeling against us, or that wanting ETA to continue there from the side of the government, because in the end ETA has actually been something very bad, which from one point on wasn't convenient for anyone to be there, but many times it has been good for the government to justify some things. (M-16)

In both these excerpts, the conflict is mainly experienced as a relation of feelings and prejudices: harm is done in the form of preconceived ideas about the ingroup, which is made explicit in excerpt 19 through the pronoun "us". This discourse also allows us to identify another narrative that has appeared several times during our interviews: the feeling that the Spanish government has instrumentalised the existence of ETA to criminalize the Basque society - the ingroup, referred to through the expressions "this feeling against us" and "it wasn't convenient for anyone".

Regarding personal identification, we found it quite interesting to observe the use of first person verbs and pronouns when talking about the past. We did not find as many as expected, but still we could identify some cases where the narrators spoke in first person about facts that they didn't actually experience:

20) The Basque conflict was because of the freedom of the Basques, when an armed group, well, when an armed group tried to, right? To ask for freedom... in the end, to ask for it. But the government did not let them, and now we are laying down the weapons or so, and seeing how it's going to end. (M-15)

It is striking to see how a 15-year-old positions himself inside a group he has physically never been part of: being born in 2002, it is clear that the narrator has never taken up arms, and therefore can impossibly be "laying down the weapons". Therefore, we consider this phenomenon to be an example of how collective identities are transmitted and expressed through discourse: the narrator feels part of that community which at one time used to hold together by the fact that they supported ETA's armed activity.

\subsection{Other observations}

Finally, we find it important to highlight not only the elements that were expressed during the interviews, but also those which remained silenced. It was striking to the researcher that none of the interviewees brought up any reference to the peace process when asked about turning points during the history of the conflict, and most of them were clueless about most of the peace initiatives when asked about them concretely these included the 1998 process of Lizarra-Garazi, the 2011 peace conference in Donostia, as well as the latest events carried out by the so-called "peace artisans".

There also seems to be a transmission void regarding the history of banned political parties and other political or civilian organisations in the Basque Country: none of the 
adolescents was able to explain which parties were banned during the first years of the 2000 's, and how this had affected political life; nor did they relate the conflict to other organizations that were declared illegal.

\section{Discussion}

Based on the distancing our interviewees showed in their discourses, we can assume that they do form part of a post-conflict generation: even though they cohabit with many, very material consequences of the political and armed conflict - they have heard about prisoners, know them indirectly, transit through memory places -, they do not feel that these aspects have a direct effect on them, but relate them to older generations such as their parents. Instead, as for their own experience, the Basque conflict is perceived by them rather in an immaterial way, in the form of feelings and prejudices.

Regarding the reconstruction of the past, we could observe how important personal and family experiences are: anecdotes and events that happened to one's own family or to somebody in the close environment - usually transmitted in the form of storytelling clearly condition the mental models of these adolescents about the history of the conflict, overemphazising certain actions, actors or situations which were relevant in those stories. These stories, as well as current conflicts, clearly condition the narratives about the past, which proves that most of the past is re-interpreted and re-built from the current social situation of the narrator, generally tending towards a positive selfpresentation.

As for the transmission of concrete knowledge, we could observe that it was rather the violent events of the conflict that have endured in the youngster's memories, instead of its political aspects: banning of political parties, peace processes or other low-impact events are rather unknown to them. Instead, they remember clearly some of ETA's main attacks, those which left many victims or very well-known victims. Furthermore, we could observe a great difference in the discourses about events that happened before 1978 and those that happened after that year, showing that discourses learnt at school were reproduced with greater certainty than discourses learnt at home or in the social environment. This leads us to highlight the importance of education when transmitting memory, as schools establish what adolescents generally consider objective truths, which they reproduce without greater questioning.

This study opens the path to deeper investigations and new questions. On one hand, we have been able to observe, if not to describe precisely, how attitudes can be transmitted within an epistemic community without exact knowledge going through the same channels: that is, how feelings about the past can remain without actually being linked to some exact historical event. This could possibly be a new hypothesis to continue elaborating on the topic.

\section{References}

Bakhtin, M., 1979. Estética de la creación verbal. Ciudad de México: Siglo XXI.

Bourdieu, P., 2008. ¿Qué significa hablar? Economía de los intercambios lingüísticos. Trans.:

E. Martínez Pérez. Madrid: Akal. 
Calsamiglia, H., and Tusón, A., 2012. Las cosas del decir: Manual de análisis del discurso. $3^{\text {rd }}$ ed. Barcelona: Planeta.

De Cillia, R., Reisigl, M., and Wodak, R., 1999. The Discursive Construction of National Identities. Discourse \& Society [online], 10(2), 149-173. Available from: https://doi.org/10.1177\%2F0957926599010002002 [Accessed 14 November 2018].

Devine, P., and Schubotz, D., 2010. "Caught up in the past"? The views of 16-year olds on community relations in Northern Ireland. Shared Space, 10, 5-22.

Etxeberria, F., Martín Beristain, C., and Pego, L., 2017. Proyecto de investigación de la tortura y malos tratos en el País Vasco entre 1960 y 2014 [online]. Commissioned by: Secretaría General de Derechos Humanos, Convivencia y Cooperación. Instituto Vasco de Criminología, December. Available from: https://www.berria.eus/dokumentuak/dokumentua1770.pdf [Accessed 14 November 2018].

Euskadi Ta Askatasuna, 2011. ETA anuncia el cese definitivo de su actividad armada. Gara [online], 20 October. Available from: https://gara.naiz.eus/eta-anuncia-cesedefinitivo-actividad-armada.php [Accessed 24 October 2018].

Fivush, R., 2010. Speaking silence: The social construction of silence in autobiographical and cultural narratives. Memory [online], 18(2), 88-98. Available from: https://doi.org/10.1080/09658210903029404 [Accessed 24 October 2018].

Fonseca, C., 2014. 1960. eta 2014. urteen artean hildakoak eragindako erakunde terroristen atentatuen auzibideari buruzko txostena: Euskal kasua [online]. Report. Eusko Jaurlaritza, Bakegintza eta Bizikidetzarako Idazkaritza Nagusia, December. pp. 167. Available from

http://www.euskadi.eus/contenidos/informacion/documentos paz convivencia/e u def/adjuntos/Terroristen\%20atentatuen\%20txostena.pdf [Accessed 24 October 2018].

Foucault, M., 1970. El orden del discurso. Trans.: A. González Troyano. Barcelona: Tusquets.

Galtung, J., 2003. Violencia cultural. Trans.: T. Toda. Gernika Gogoratuz [online], working paper 14. Available from:

https://www.gernikagogoratuz.org/web/uploads/documentos/202892edd66aafe5c 03dacf1298fd7f8938fae76.pdf [Accessed 24 October 2018].

Halbwachs, M., 2004. La memoria colectiva. Prensas Universitarias Zaragoza.

Idoiaga, P., and Ramírez de la Piscina, T., 2002. Al filo de la (in)comunicación: Prensa y conflicto vasco. Madrid: Fundamentos.

Jäger, M., 2004. Diskursanalyse: Ein Verfahren zur kritischen Rekonstruktion von Machtbeziehungen. In: R. Becker and B. Kortendiek, eds., Handbuch Frauen- und Geschlechterforschung: Theorie, Methoden, Empirie. Wiesbaden: Verlag für Sozialwissenschaften.

Lederach, J.P., 1998. Construyendo la paz: Reconciliación sostenible en sociedades divididas. Gernika-Lumo/Bilbao: Bakeaz/Gernika Gogoratuz. 
Lemke, J.L., 1995. Textual politics: Discourse and Social Dynamics. $1^{\text {st }}$ ed. London: Taylor \& Francis.

Lizarralde, A., 2017. Boluntario baten ibilerak, eta beste. Oñati. Self-edited.

Murua Uria, I., 2015. The End of ETA: errelatuaren borroka akademian. Jakin, 209, 101116.

Nora, P., 2002. L'avènement mondial de la mémoire. Transit, 22, 1-8.

Reidy, C.M., et al., 2015. The political socialization of youth in a post-conflict community. International Journal of Intercultural Relations [online], 45, 11-23. Available from: https:// dx.doi.org/10.1016/j.ijintrel.2014.12.005 [Accessed 14 November 2018].

Shahzad, F., 2011. Collective memories: A complex construction. Memory Studies [online], 5(4), 378-391. Available from: https://doi.org/10.1177/1750698011419121 [Accessed 24 October 2018].

Uson González, I., Urrutia Asua, G., and De la Cruz Ayuso, C., 2017. Unibertsitateko gazteek Euskadin bizi izan den terrorismoari eta giza eskubideen urraketei buruz dakitena eta duten diskurtsoa. Bilbao: Instituto de Derechos Humanos Pedro Arrupe, pp. 142 .

van Dijk, T.A., 1987. Communicating racism. Newbury Park: Sage.

van Dijk, T.A., 2003. The Discourse-Knowledge Interface [online]. In: G. Weiss and R. Wodak, eds., Critical Discourse Analysis. Theory and Interdisciplinarity. New York: Palgrave Macmillan, pp. 85-108. Available from:

http://www.discourses.org/OldArticles/Discourse-knowledge\%20interface.pdf [Accessed 14 November 2018].

van Dijk, T.A., 2005. Política, ideología y discurso. Trans.: A.I. Méndez. Quórum Académico [online], 2(2), 15-47. Available from:

http://www.discursos.org/oldarticles/Politica\%20ideologia.pdf [Accessed 24 October 2018].

van Leeuwen, T., and Wodak, R., 1999. Legitimizing immigration control: a discoursehistorical analysis. Discourse Studies [online], 1(1), 83-117. Available from: https://doi.org/10.1177\%2F1461445699001001005 [Accessed 14 November 2018].

Velte, S., 2016. La representación de los presos políticos vascos en la prensa española (2011-2016). Discurso \& Sociedad [online], 10(3), 491-544. Available from: http://www.dissoc.org/ediciones/v10n03/DS10\%283\%29Velte.pdf [Accessed 24 October 2018].

Whitfield, T., 2014. Endgame for ETA: Elusive Peace in the Basque Country. Oxford University Press.

Wilches Tinjacá, J.A., and Hernández Pérez, M., 2016. Jóvenes universitarios: percepciones y encuestas sobre conflicto armado y paz en Colombia. Reflexiones [online], 95(2), 33-55. Available from: http://www.redalyc.org/articulo.oa?id=72950004003 [Accessed 24 October 2018]. 
Wodak, R., and Fairclough, N., 1997. Critical Discourse Analysis. In: T. van Dijk, ed., Discourse Studies: A multidisciplinary introduction. Vol. 2. Discourse as social interaction. London: Sage, pp. 258-284. 